\title{
Presence of Egg in the Oviduct Uterus Stimulates Shell Gland Calcium Secretion in the Hen
}

\author{
Tadashi NAKADA \\ Department of Animal Science, University of the \\ Rukyus, Nishihara, Okinawa 903-01
}

\begin{abstract}
Shell glands of the uterus of the hen oviduct secrete fluid which contains a high percentage of calcium ${ }^{1)}$. The secretion rate of the fluid is higher during the time when normally ovulated ovum (ovum) ${ }^{2)}$ or an artificial yolk-containing egg-like mass ${ }^{2}$ is present in the uterus comparing with other times ${ }^{2)}$. However, whether the higher secretion rate during that time is caused by a certain stimulus associated with the presence of an egg or an egg-like mass has not been completely determined, since there remains a possibility that the higher secretion rate is due to a diurnal rhythm of the secretory activity of the uterus. The present experiments were performed to demonstrate that the presence of the egg in the uterus stimulates the secretion of the shell gland fluid. For this purpose, the volume of the shell gland fluid and its calcium concentration were measured at definite of a day in hens of which ovulated ovum was artificially retained at various regions of the oviduct by a surgical ligation.
\end{abstract}

Key words : Shell gland, Calcium

(Jpn. Poult. Sci., 27 : 162-163, 1990)

\section{Materials and Methods}

Single Comb White Leghorn hens (17 month-old, 1.8-2.0 kg BW) were kept in individual cages under $14 \mathrm{~h}$ light $(0500-1900 \mathrm{~h}) / 10 \mathrm{~h}$ darkness and given feed and water ad libitum. The hens exhibiting 4-6 eggs in each clutch separated from others by one day pause for more than 2 weeks prior to experiments were used. The time of ovulation of the second ovum of the clutch $\left(\mathrm{C}_{2}\right)$ was estimated based on the individual laying record.

To retain the egg at various regions of the oviduct, laparotomy was carried out under Nembutal anesthesia. An incision with about $5 \mathrm{~cm}$ length was made on the left side of the abdominal wall when an egg was located in the magnum, isthmus or an upper portion of the uterus. Exposing the oviduct, a ligation was conducted at each region of the oviduct by the use of a surgical thread (JIS No. 9). In sham operated hens, the same handling was conducted.

Shell gland fluid was collected at a definite time $(2300 \mathrm{~h})$ of a day, i.e., at about $15 \mathrm{~h}$ after $\mathrm{C}_{2}$ ovulation. At this time, the egg was placed in the portion just anterior to a ligated position in the operated hens and in the uterine pouch in the sham operated hens. Procedures for the fluid collection, measurements of the calcium concentration and statistical analyses of the results obtained were described previously ${ }^{2}$.

Received Jul. 15, 1989 
Table 1. Volume, calcium concentration and calcium content of the shell gland fluid collected from the uterus of the hen at a definite time of a day

\begin{tabular}{|c|c|c|c|c|}
\hline \multirow{2}{*}{$\begin{array}{l}\text { Position } \\
\text { of egg }\end{array}$} & \multirow{2}{*}{$\begin{array}{l}\text { No. of } \\
\text { hens }\end{array}$} & \multicolumn{3}{|c|}{ Shell glang fluid } \\
\hline & & $\begin{array}{l}\text { Volume } \\
(\mathrm{m} l)\end{array}$ & $\begin{array}{c}\text { Ca concentration } \\
(\mathrm{mg} / \mathrm{d} l)\end{array}$ & $\begin{array}{l}\text { Ca content }{ }^{1)} \\
\text { (mg/fluid) }\end{array}$ \\
\hline & & $*$ & $*$ & $*$ \\
\hline Magnum\# & 8 & $0.8 \pm 0.4^{\mathrm{a} * *}$ & $30.5 \pm 2.2^{\mathrm{a} * *}$ & $24.4 \pm 1.1^{\mathrm{a} * *}$ \\
\hline Isthmus \# & 8 & $0.7 \pm 0.3^{\mathrm{a}}$ & $29.9 \pm 3.6^{\mathrm{a}}$ & $20.9 \pm 3.6^{\mathrm{a}}$ \\
\hline Upper Uterus\# & 10 & $0.8 \pm 0.3^{\mathrm{a}}$ & $32.7 \pm 5.4^{\mathrm{a}}$ & $24.5 \pm 1.5^{\mathrm{a}}$ \\
\hline Uterine Pouch\#\# & 15 & $3.6 \pm 0.1^{\mathrm{b}}$ & $29.8 \pm 5.3^{\mathrm{a}}$ & $105.7 \pm 4.3^{b}$ \\
\hline
\end{tabular}

Fluid was collected at $2300 \mathrm{~h}$ (about $15 \mathrm{~h}$ after $\mathrm{C}_{2}$ ovulation).

1) Obtained by calculation

\# Egg was artificially retained in an indicated region of the oviduct by a surgical ligation

\#\# Sham operated hens

* Mean \pm SD

** Means with a different letter in a column are significantly different $(\mathrm{P}<0.01)$ by

Newman-Kuels' test.

\section{Results and Discussion}

The volume of the shell gland fluid and its calcium concentration and content at 15 $\mathrm{h}$ after $\mathrm{C}_{2}$ ovulation were greater when the egg was located in the uterine pouch than when the egg was artificially retained in the magnum, isthmus or upper uterus (Table 1). These results accord with the previous findings obrained from hens having a normal $\mathrm{egg}^{2)}$ or an egg-like mass ${ }^{2)}$ at various times of a day. It is concluded from the present results that an increase in the secretion of the shell gland fluid is closely related to the presence of the egg in the uterine pouch.

\section{Acknowledgment}

The author wish to express his sincere thank to Dr. Katsuhide TANAKA of Gifu University, for his critical reading for manuscript.

\section{References}

1) Ogasawara, T., O. Koga and H. Nishiyama (1974) Effect of a shell gland irritant on the secretion rate, calcium and inorganic phosphorus levels of the shell gland fluid in the laying hen. Jpn. J. Zootech. Sci., 45:668-673.

2) Nakada, T. and Koga, O. (1990) Stimulation of secretion of shell gland fluid and calcium by the presence of ovum or ovum-like mass containing artificial york in the oviduct uterus of the hen. Jpn. Poult. Sci., $27: 21-28$. 